\title{
Martyna Komarowska
}

Uniwersytet w Białymstoku

martynakomarowska@gmail.com

\section{Dopuszczalność umowy zrzeczenia się zachowku. Glosa do uchwały Sądu Najwyższego z dnia 17 marca 2017 r. (III CZP 110/16)}

\author{
Admissibility of a Contract on a Waiver of Legitime. Commentary to the Supreme \\ Court's Resolution Adopted on 17 March 2017 (III Czp 110/16)
}

\begin{abstract}
The Supreme Court in its resolution adopted on 17th March 2017 r. (III CZP 110/16) indicated that "It is admissible to conclude a contract on a waiver of legitime (Article 1048 of the Civil Code)". So far this matter has been presented diversely in the law doctrine, with the majority of voices in favour of the admissibility of such contract. A legal basis of this institution has been deduced from the provision enabling to conclude a contract on a waiver of succession, using a maiori ad maius inference - if it is permitted to waive of succession, it may also be permitted to waive of legitime, which is a right that derivates from the right of succession. The argument for the admissibility of the contract on a waiver of legitime is enlarging the freedom of a person to dispose of their assets after death. Concluding such a contract is particularly essential when a sole proprietor makes a succession plan for his enterprise. The Supreme Court's standpoint should be assessed positively, it emphasizes the significance of freedom of succession in all institutions of inheritance law.
\end{abstract}

Keywords: inheritance law, legitime, waiver of legitime, waiver of succession

Słowa kluczowe: prawo spadkowe, zachowek, zrzeczenie się zachowku, zrzeczenie się dziedziczenia

\section{Wprowadzenie}

W uchwale z dnia 17 marca 2017 r. ${ }^{1}$ Sąd Najwyższy ${ }^{2}$ orzekł, że: „Dopuszczalne jest zawarcie umowy zrzeczenia się prawa do zachowku (art. 1048 kc. $^{3}$ )”. Dotychczas

$1 \quad$ III CZP 110/16, Lex nr 2248747.

2 Dalej: „SN”.

3 Ustawa z dnia 23 kwietnia 1964 r. - Kodeks cywilny (tekst jedn. Dz.U. z 2017 r. poz. 459 ze zm.), dalej: „kc.” 
kwestia ta była różnorodnie przedstawiana $\mathrm{w}$ doktrynie ${ }^{4}$. Stanowisko SN wyrażone w powyższej uchwale z pewnością stanowi ważny głos w dyskusji na temat dopuszczalności umowy zrzeczenia się zachowku de lege lata.

\section{Stan faktyczny}

Uchwała SN stanowi odpowiedź na pytanie prawne zadane przez sąd rozpoznający zażalenie na odmowę dokonania czynności notarialnej. Do notariusza zgłosił się ojciec i jego syn w celu zawarcia umowy zrzeczenia się zachowku. Uzasadnieniem ich zamiaru było doprowadzenie do zwiększenia swobody ojca prowadzącego przedsiębiorstwo rodzinne w planowaniu sukcesji. Intencją przyszłego spadkodawcy było przekazanie przedsiębiorstwa tylko jednemu ze swoich dzieci. Umowa o zrzeczenie się dziedziczenia nie odpowiadała stronom ze względu na skutek w postaci zwiększenia podstawy wymiaru ewentualnych roszczeń z tytułu zachowku innych uprawnionych podmiotów.

Notariusz odmówił zawarcia umowy zrzeczenia się zachowku, powołując się na jej sprzeczność z prawem na podstawie art. 81 ustawy z dnia 14 lutego $1991 \mathrm{r}$. Prawo o notariacie ${ }^{5}$, ze względu na naruszenie art. 1047 kc., który zakazuje zawierania innych umów o spadek po osobie żyjącej niż wyraźnie przewidziane w przepisach. W ocenie notariusza niezasadne jest zastosowanie wykładni art. 1048 kc., dopuszczającego zawarcie umowy zrzeczenia się dziedziczenia, z zastosowaniem wnioskowania a maiori ad minus, gdyż prawo do zachowku nie wynika wprost z prawa do dziedziczenia, a funkcjonuje obok niego. Dodatkowo powołał się na wykładnię historyczną - skoro ustawodawca świadomie nie recypował przepisu zawartego w art. $10 \$ 2$ dekretu z dnia 8 października 1946 r. Prawo spadkowe ${ }^{6}$, który wyraźnie wskazywał, że zrzeczenie się dziedziczenia $\mathrm{w}$ drodze umowy może być ograniczone do zrzeczenia się tylko prawa do zachowku, to czynność ta w świetle aktualnie obowiązującego prawa jest niedopuszczalna.

Składający zażalenie podniósł, że umowa zrzeczenia się dziedziczenia zwiększa zakres swobody spadkobiercy w rozporządzaniu swoim majątkiem na wypadek śmierci, co odpowiada celowi art. 1047 kc. Zakaz zawierania umów o spadek po osobie żyjącej powinien w ocenie składającego zażalenie być interpretowany w świetle standardów konstytucyjnych, przy zachowaniu zasady proporcjonalności.

\footnotetext{
$4 \quad$ Przegląd piśmiennictwa poniżej.

5 Tekst jedn. Dz.U. z 2016 r. poz. 1796 ze zm.

6 Dz.U. Nr 60, poz. 328 ze zm.
} 


\section{Stanowisko Sądu Najwyższego}

Odpowiadając na pytanie prawne postawione w powyższym stanie faktycznym, SN uznał za dopuszczalne zawarcie umowy zrzeczenia się zachowku. Odwołał się do stanowisk prezentowanych w doktrynie, opowiadających się zarówno za dopuszczalnością tej czynności, jak i przeciwnych, a także do nielicznych wypowiedzi pojawiających się w orzecznictwie ${ }^{7}$, w tym wyroku Trybunału Konstytucyjnego ${ }^{8}$.

SN stanowczo odrzucił rezultaty wykładni historycznej opierającej się na fakcie braku przeniesienia do aktualnego kc. treści przepisu art. $10 \$ 2$ dekretu Prawo spadkowe. Wskazał, że: „Nie jest zasadą, że brak regulacji prawnej konkretnej instytucji (określonego typu umowy) oznacza jej wykluczenie z systemu prawa. Nie jest bowiem tak, że dozwolone jest to wszystko, co zostało wyraźnie prawem uregulowane", a brak wyraźnego przepisu, nawet pomimo tego, że wcześniej istniał w danym porządku prawnym, nie oznacza, iż dana czynność jest niedozwolona.

Dopuszczalność umowy zrzeczenia się zachowku SN wywiódł z art. 1048 kc. i skutku, jaki wywiera zawarcie umowy zrzeczenia się dziedziczenia, prowadzące również do pozbawienia uprawnionego prawa do zachowku. Zatem, skoro spadkodawca i spadkobierca zawierający umowę mogą doprowadzić do pozbawienia tego ostatniego dziedziczenia, w tym także prawa do zachowku, to maiore ad minus, mogą również ograniczyć skutki tej czynności jedynie do wyłączenia prawa do zachowku.

Niezasadne zdaniem SN są argumenty wykluczające omawianą umowę ze względu na negatywny wpływ na sytuację prawną pozostałych podmiotów. W istocie, zrzeczenie się prawa do zachowku nie modyfikuje uprawnień innych osób, w szczególności nie prowadzi do zwiększenia zachowków innych uprawnionych, co ma miejsce w przypadku zrzeczenia się dziedziczenia.

Konkludując SN wskazał, że wyłączenie możliwości zawarcia umowy zrzeczenia się zachowku nie ma gruntownego i przekonującego uzasadnienia oraz naruszałoby zasadę swobody testowania, a w aktualnym orzecznictwie można dostrzec tendencję do poszukiwania rozwiązań pozwalających na elastyczne i precyzyjne planowanie sukcesji przez spadkodawców9. Dowolność w dokonywaniu rozporządzeń na wypadek śmierci szczególnie istotna jest w przypadku przedsiębiorstw, gdyż realizacja roszczeń wynikających z prawa do zachowku zagraża prowadzonej działalności

7 Postanowienie Sądu Najwyższego z dnia 21 kwietnia 2004 r., III CK 353/02, Lex nr 585802; wyrok Sądu Apelacyjnego w Krakowie z dnia 3 grudnia 2015 r., I ACa 1177/15, Lex nr 1993133.

$8 \quad$ Wyrok Trybunału Konstytucyjnego z dnia 25 lipca 2013 r., P 56/11, Dz.U. z 2013 r. poz. 1003.

9 W komentowanym orzeczeniu SN powołał się na uchwałę SN z dnia 13 grudnia 2013 r., III CZP 79/13, Lex nr 1400579, dopuszczającą zawarcie umowy darowizny na wypadek śmierci oraz uchwałę SN z dnia 18 lipca 2012 r., III CZP 46/12, Lex nr 1211870, w której przyjęto, że testator może zapisać w swej ostatniej woli także rzecz czy prawo, które nie należą do jego majątku w chwili sporządzania testamentu, tj. w stanie faktycznym będącym podstawą tej uchwały - rzeczy należącej do majątku wspólnego małżonków pozostających w ustroju wspólności ustawowej. 
gospodarczej, płynności finansowej, a niekiedy nawet może prowadzić do likwidacji przedsiębiorstwa.

\section{Ocena stanowiska Sądu Najwyższego}

\subsection{Dopuszczalność umowy zrzeczenia się zachowku na gruncie aktualnego stanu prawnego}

$\mathrm{Na}$ gruncie obowiązującego prawa dopuszczalność umowy zrzeczenia się zachowku nie jest jednoznacznie aprobowana w doktrynie. Według E. Skowrońskiej-Bocian i J. Wiercińskiego „wobec ograniczenia możliwości zrzeczenia się dziedziczenia jedynie do dziedziczenia ustawowego, a także wobec tego, że zrzekający się (oraz jego zstępni) jest traktowany tak, jakby nie dożył otwarcia spadku, zasadniczo zbędne stało się odrębne unormowanie dopuszczające możliwość zrzeczenia się jedynie prawa do zachowku (por. art. $10 \$ 2$ d.p.s. - tj. dekretu Prawo spadkowe - przyp. M.K.). Spadkobierca ustawowy, który zrzekł się dziedziczenia i jest traktowany tak, jakby nie dożył otwarcia spadku, nie nabędzie w żadnym przypadku prawa do zachowku”"10. Inni, bardziej liczni, dopuszczają tę możliwośćc ${ }^{11}$. M. Pazdan ${ }^{12}$ zaznacza, że „zrzeczenie się jedynie prawa do zachowku może być praktycznie użyteczne, w sytuacji gdy uprawnionemu do zachowku należałby się zachowek o wartości znacznie przewyższającej wartość uzyskanego przez niego majątku w ramach

10 E. Skowrońska-Bocian, J. Wierciński, (w:) J. Gudowski (red.), Kodeks cywilny. Komentarz. T. VI. Spadki, Lex 2017, komentarz do art. 1049, nb 5. Podobnie za niedopuszczalnością umowy zrzeczenia się zachowku opowiada się J. Pietrzykowski, (w:) J. Pietrzykowski (red.) Kodeks cywilny. Komentarz, t. 3, Warszawa 1972, s. 1989; L. Stecki, (w:) J. Winiarz (red.), Kodeks cywilny z komentarzem, t. 2, Warszawa 1989, s. 900. W przeważającej mierze krytycznie wypowiada się również W. Borysiak, (w:) K. Osajda (red.), Kodeks cywilny. Komentarz, t. 3. Spadki, Warszawa 2013, s. 1133-1134 - zob. szersze odniesienie do jego argumentacji poniżej.

11 Zob. przegląd stanowisk powołany przez M. Pazdana, (w:) B. Kordasiewicz (red.), System prawa prywatnego. Prawo spadkowe, Tom 10, Warszawa 2015, s. 1144: W. Hans, Umowy dotyczące spadku, „Nowe Prawo” 1967, nr 2, s. 244; J. Kosik, (w:) System prawa cywilnego, t. 4, Wrocław 1976, s. 586; M. Pazdan, Umowa o zrzeczenie się dziedziczenia w polskim prawie spadkowym, „Rejent” 1997, nr 4, s. 194; A. Doliwa, Umowy dotyczące spadku, „Studia Prawa Prywatnego” 2008, nr 1, s. 137; E. Rott-Pietrzyk, Umowa o zrzeczenie się dziedziczenia - uwagi „de lege lata” i „de lege ferenda”, „Rejent” 2006, nr 3, s. 117-118; E. Niezbecka, (w:) A. Kidyba (red.), Kodeks cywilny. Komentarz, t. 4: Spadki, Warszawa 2012, s. 372; P. Księżak, Zachowek w polskim prawie spadkowym, Warszawa 2012, s. 130 i n., również A. Ganicz, Uprawnieni i zobowiązani z tytułu zachowku w polskim prawie spadkowym, „Rejent” 2011, nr 2, s. 25-53; bez wyraźnego opowiedzenia się za żadnym ze stanowisk J. Knabe, (w:) J. Ciszewski (red.), Kodeks cywilny. Komentarz, Lex 2014, komentarz do art. 1049, nb 5. Szerzej omówienie stanowisk doktryny zob. P. Księżak, Zachowek..., op. cit., s. 131-136 oraz M. Panek, Dopuszczalność zrzeczenia się zachowku w prawie polskim, „Studia Iuridica Toruniensa” 2015, t. XVI, s. 94-107.

12 M. Pazdan, (w:) K. Pietrzykowski (red.), Kodeks cywilny. Komentarz do artykułów 450-1088, t. II, Warszawa 2011, s. 1272. 
dziedziczenia (ustawowego lub testamentowego, co może mieć miejsce przykładowo, gdy spadkodawca dokonał za życia darowizn o znacznej wartości, a obdarowani byliby zobowiązani do zaspokojenia roszczenia o zachowek, którego podstawą wyliczenia jest również wartość przedmiotu tego nieodpłatnego przysporzenia. Zrzeczenie się zachowku może zatem być korzystne dla obdarowanych. Należy przychylić się do stanowiska SN wyrażonego w komentowanym orzeczeniu oraz doktryny, które dopuszcza możliwość zawarcia umowy zrzeczenia się zachowku.

Umowa zrzeczenia się zachowku była przewidziana wcześniej w dekrecie Prawo spadkowe, ale jak słusznie wskazał SN, brak regulacji nie oznacza, że nie można dokonać danej czynności prawnej, o ile nie sprzeciwia się obowiązującemu prawu lub zasadom współżycia społecznego (art. $58 \mathrm{kc}$. oraz $353^{1} \mathrm{kc}$. w przypadku zawierania umów). Fundamentalne zasady prawa cywilnego - swoboda umów i wolność stron w kształtowaniu swojego stosunku prawa ${ }^{13}$ - przemawiający za zasadnością przyjęcia za dopuszczalne zawarcia umowy zrzeczenia się zachowku, przy zastrzeżeniu, że przepisy szczególne dotyczące spadkobrania nie sprzeciwiają się jej ${ }^{14}$.

Umowa zrzeczenia się zachowku wpływa na sytuację prawną trzech podmiotów. Prawo do zachowku istnieje na płaszczyźnie pomiędzy spadkodawcą a uprawnionym. Natomiast roszczenie o zachowek, które powstaje w chwili śmierci spadkodawcy - to dług obciążający spadkobiercę i innych zobowiązanych ${ }^{15}$. Przyczyną powstania tej wierzytelności jest jednak zachowanie spadkodawcy, który nie zrealizował prawa do zachowku uprawnionego poprzez powołanie go do dziedziczenia lub dokonanie zapisu zwykłego, czy też windykacyjnego lub poprzez czynności dokonane jeszcze za życia, np. darowizny. Zawierając umowę zrzeczenia się zachowku, dwie zainteresowane strony - spadkodawca oraz spadkobierca wspólnie postanawiają, że prawo to pomiędzy nimi wygaśnie, przez co zobowiązani następnie do zaspokojenia wynikającego z niego roszczenia - przyszli spadkobiercy spadkodawcy i inne zobowiązane osoby (spadkobierca, zapisobierca windykacyjny, obdarowany), nie będą obciążone takim długiem. Skoro zarówno spadkodawca, pierwotnie zobowiązany z tytułu zachowku, jak i uprawniony zgodnie postanawiają w drodze umowy, że prawo zachowku wygasa, nie ma uzasadnienia do uznania takiej czynności prawnej za niedopuszczalną.

Można byłoby przyjąć, że uprawniony do zachowku, jeżeli rezygnuje z tego prawa, to powinien nie realizować swojego roszczenia po śmierci spadkodawcy,

13 O swobodzie stron w kształtowaniu swoich stosunków prawnych zob. W. J. Katner, (w:) W. J. Katner (red.), System prawa prywatnego. Prawo zobowiązań - umowy nienazwane. Tom 9, Warszawa 2015, s. 3-6 i literatura tam wskazywana.

14 Zob. prawnoporównawcze uwagi na temat dopuszczalności umowy zrzeczenia się zachowku P. Księżak, Zachowek..., op. cit., s. 130-131.

$15 \mathrm{Tj}$. zapisobiercę windykacyjnego na podstawie art. $991^{1} \mathrm{kc}$. oraz obdarowanego na podstawie art. 1000 kc. Szerzej o istocie zachowku, prawa do zachowku i roszczeniu o zachowek zob. P. Księżak, Zachowek..., op. cit., s. 63-72; A. Szpunar, Uwagi o prawie o zachowku, „Rejent” 2002, nr 6 (134), s. 13-27. 
przez co umowa zrzeczenia się zachowku jest zbędna. Jednak zawarcie porozumienia zapewnia, że zamiar uprawnionego będzie egzekwowany, nie zmieni się pod wpływem okoliczności, na które spadkodawca nie ma wpływu. Jak wskazuje A. Doliwa ${ }^{16}$ na temat funkcji umowy zrzeczenia się dziedziczenia: ,jest zwykle instrumentem wykorzystywanym w celu ukształtowania, zgodnie z poczuciem sprawiedliwości, stosunków w rodzinie, na wypadek śmierci spadkodawcy - w sytuacji, gdy ten ostatni wyposażył już za życia jedno bądź tylko niektóre z dzieci (i dlatego zawiera obecnie z tym wyposażonym już potomkiem umowę z art. 1048 kc.)”. Analogicznie w przypadku zrzeczenia się zachowku można wskazać, że jest to instrument, który może wykorzystać spadkodawca za życia, aby uregulować stosunki w rodzinie wynikające $z$ jego śmierci, eliminując ewentualne spory związane z sukcesją, a mogące powstać pomiędzy spadkobiercami i innymi zobowiązanymi do zrealizowania roszczeń zachowkowych oraz uprawnionych $\mathrm{z}$ tego tytułu ${ }^{17}$. Spadkodawca ma w ten sposób zwiększoną kontrolę nad tym, co stanie się z jego majątkiem po jego śmierci oraz jak sprawy związane z sukcesją wpłyną na stosunki w rodzinie.

Omawiana umowa stanowi uzupełnienie instytucji wydziedziczenia przewidzianej w art. 1008 kc. ${ }^{18}$ Jednostronnie spadkodawca może pozbawić uprawnionego zachowku tylko wówczas, gdy zachodzą przesłanki enumeratywnie wskazane w powołanym przepisie. Spadkodawca i uprawniony działając wspólnie mogą natomiast doprowadzić do wyłączenia tego prawa również w innych sytuacjach. Umowa zrzeczenia się dziedziczenia ${ }^{19}$, na mocy której spadkobierca wyzbywa się zarówno prawa do dziedziczenia, jak i zachowku, prowadzi do niekorzystnych skutków poprzez zwiększenie roszczeń zachowkowych innych uprawnionych. Zatem umowa zrzeczenia się zachowku jest optymalnym rozwiązaniem prowadzącym do zwiększenia swobody testowania spadkodawcy o zachowek należny uprawnionemu, bez modyfikacji sytuacji prawnej innych podmiotów.

Wywiedzenie podstawy prawnej pozwalającej na zawarcie umowy zrzeczenia się zachowku z art. 1048 kc. dopuszczającego zrzeczenie się dziedziczenia w drodze umowy zawartej pomiędzy spadkodawcą i potencjalnym spadkobiercą, opiera się na wnioskowaniu ad maiori ad minus - skoro można zrzec się dziedziczenia, tym

16 A. Doliwa, Umowy..., op. cit., s. 135.

17 Zob. przykład na temat powstania sporów w rodzinie w wyniku oddziaływania instytucji zachowku oraz konkluzja: „zachowek czasami jest w stanie przyczynić się do ochrony rodziny i zabezpieczenia słusznych interesów majątkowych jej członków, jednak równie dobrze skutkować może jej podziałem i eskalacją konfliktów pomiędzy bliskimi krewnymi”, K. Smoter, Zachowek jako ograniczenie testowania, „Państwo i Prawo” 2013, nr 9, s. 61.

18 Szerzej zob. R.M. Paliwoda, Skutki prawne wydziedziczenia w polskim prawie spadkowym, „Przegląd Sądowy” 2013, nr 10, s. 43-54; M. Pogonowski, Wydziedziczenie. Zarys problematyki, „Rejent” 2005, nr 4, s. 121.

19 O umowie zrzeczenia się dziedziczenia szerzej zob. G. Wolak, Umowa zrzeczenia się dziedziczenia w polskim prawie cywilnym, Warszawa 2016. 
bardziej można zrzec się prawa do zachowku, który jest uprawnieniem pochodnym do dziedziczenia, a też o mniejszej „wartości”. Wnioskowanie to można poprowadzić dalej - skoro można zrzec się prawa do zachowku, można zrzec się również jego części, czy też zastrzec warunek. Uznanie za dopuszczalne zawarcie omawianej umowy otwiera zatem drogę dla różnych konstrukcji prowadzących do realnego zmniejszenia zachowku ${ }^{20}$. Ich dopuszczalność w świetle obowiązującego prawa winna być rozpatrywana osobno.

\subsection{Umowa zrzeczenia się zachowku jako zwiększenie swobody testowania}

W. Borysiak ${ }^{21}$ powołuje się na poglądy autorów dopuszczających możliwość zawarcia umowy zrzeczenia się dziedziczenia. Wskazuje jednocześnie, że „wątpliwości budzą jednak argumenty natury jurydycznej. Nie do końca poprawne jest bowiem wywodzenie dopuszczalności zawarcia takiej umowy z rozumowania opartego na wykładni a maiori ad minus, gdyż prawo do zachowku nie wywodzi się wprost z prawa do dziedziczenia. Można powiedzieć, że funkcjonuje z woli ustawodawcy niejako obok niego". Autor ten wskazuje, że zrzeczenie się zachowku jest umową dziedziczenia różną od zrzeczenia się dziedziczenia, a nie ma wyraźnej podstawy prawnej, co stoi w sprzeczności z treścią art. 1047 kc. zakazującego zawierania umów o spadek po osobie żyjącej, o ile ustawa nie dopuszcza takiej możliwości. Podsumowując W. Borysiak przyjmuje, że: „Kwestia dopuszczalności takiej umowy powinna zostać rozstrzygnięta w sposób wyraźny przez ustawodawcę"22.

Jednak należy przyjąć, że uprawniona jest tu wykładnia rozszerzająca ${ }^{23}$. Uwzględnienia wymaga sama istota normy przewidzianej w art. 1047 kc. Prawo nie dopuszcza porozumień dotyczących spadku zawieranych za życia danej osoby, gdyż krępowałyby swobodę testatora. Nie mógłby odwołać swojej ostatniej woli poprzez jednostronną czynność prawną, gdyż związał się umową z drugą stroną, która musiałaby wyrazić zgodę na zmianę lub rozwiązanie powstałego w ten sposób stosunku prawnego $^{24}$. W przypadku umowy zrzeczenia się zachowku takie zagrożenie nie powstaje. Jeżeli spadkodawca zmieni zdanie, to znaczy jego wolą będzie uposażenie uprawnionego do zachowku - może powołać go do dziedziczenia lub dokonać na jego rzecz zapisu zwykłego lub zapisu windykacyjnego. Co prawda, uprawnionemu nie będzie już przysługiwało samo prawo do zachowku, ale będzie uposażony przez spadkodawcę. Wola spadkodawcy nie jest zatem w całości ograniczona. To uprawniony do zachowku nie będzie mógł zniweczyć skutków zrzeczenia się prawa do zachowku (poza powołaniem się na wadę jego oświadczenia woli). Zakaz zawierania umów po osobie żyjącej nie ma jednak na celu ochrony uprawnionego do zachowku, a spad-

\footnotetext{
20 Zob. P. Księżak, Zachowek..., op. cit., s. 139-140.

21 W. Borysiak, Kodeks..., op. cit., s. 1133.

22 Ibidem, s. 1133.

23 Tak A. Doliwa, Umowy..., op. cit., s. 138.

24 Ibidem, s. 130.
} 
kodawcy. Odnosząc się zatem do ratio legis zakazu zawierania umów dotyczących spadku z osobą żyjącą oraz wyjątku od tej zasady - zrzeczenia się dziedziczenia, należy wskazać, że uprawnione jest wywiedzenie z art. 1048 kc. podstawy do zawarcia umowy zrzeczenia się zachowku, jako instytucji zgodnej z istotą art. 1047 kc., prowadzącej do zwiększenia chronionej swobody spadkodawcy.

Zasadami prawa spadkowego są ochrona dziedziczenia i swoboda testowania ${ }^{25}$. Wyjątkiem od nich jest instytucja zachowku, która prowadzi do umniejszenia możliwości spadkodawcy do dowolnego dysponowania swoim majątkiem na wypadek śmierci. Nie jest zasadne zatem rozszerzanie zakresu oddziaływania zachowku, uniemożliwiając zawarcie umowy zrzeczenia się tego prawa. Należy powrócić do jednej z najważniejszych zasad prawa spadkowego - swobody testowania. Wykładnia art. 1048 kc. dopuszczająca zrzeczenie się zachowku jest dopuszczalna, gdyż jest to wyjątek od zasady zakazu zawierania umów o zrzeczenie się dziedziczenia, którego jednak uzasadnieniem jest ochrona dziedziczenia i swobody testowania. Skoro zrzeczenie się zachowku prowadzi do zwiększenia swobody testowania, nie narusza to zakazu zawierania umów dotyczących spadku po osobie żyjącej, którego uzasadnieniem jest ochrona swobody testatora.

Dodatkowo należy zwrócić uwagę na pojawiające się wypowiedzi podkreślające, że w aktualnej rzeczywistości gospodarczej i społecznej zachowek może być uznany za zbyt daleko idące ograniczenie swobody testowania, wynikającej z konstytucyjnie chronionej zasady prawa do dziedziczenia ${ }^{26}$. Wcześniejsze uzasadnienie tej instytucji, tj. konieczność przekazania części majątku przez spadkodawcę określonym najbliższym mu osobom, dzieciom, małżonkowi, z uwagi na zaspokojenie ich potrzeb, traci aktualnie na znaczeniu ze względu na wydłużenie przeciętnej długości życia i większą zamożność społeczeństwa ${ }^{27}$. Quasi-alimentacyjne świadczenie, jakim jest zachowek, w obecnych realiach społecznych i gospodarczych może stanowić zbyt dużą ingerencję w prawo do dziedziczenia i swobodę testowania ${ }^{28}$. Dopuszczenie zatem de lege lata możliwości zawarcia umowy zrzeczenia się zachowku służy uelastycznieniu tej instytucji wobec zmienionej rzeczywistości. Spadkodawca i uprawniony do za-

S. Wójcik, F. Zoll, (w:) B. Kordasiewicz (red.), System..., op. cit., s. 336.

Ibidem, s. 338; K. Smoter, Zachowek..., op. cit., s. 54-66.

O ratio legis i funkcjach instytucji zachowku zob. M. Załucki, Przyszłość zachowku w prawie polskim, „Kwartalnik Prawa Prywatnego” 2012, nr 2, s. 530 i n.; P. Księżak, Zachowek..., op. cit., s. 49 i n.; J. Bieluk, Rozliczenia związane ze spadkiem, Warszawa 2015, s. 80-81; wyrok SN z dnia 13 czerwca 2013 r., V CSK 385/12, Lex nr 1375506.

Co prawda Trybunał Konstytucyjny w wyroku z dnia 25 lipca 2013 r., P 56/11, op. cit. orzekł o zgodności zachowku z Konstytucją RP, jednak konkludując wskazał, że: „Nie oznacza to jednak, że przyjęty przez prawodawcę krąg uprawnionych do zachowku oraz wysokość roszczenia o zachowek Trybunał uznał za optymalny i jedyny możliwy w świetle regulacji konstytucyjnej. Prawodawcy przysługuje w tym zakresie swoboda regulacyjna, włącznie ze zmianą ustawowego systemu ochrony najbliższych spadkodawcy m.in. na model mieszany lub model roszczeń alimentacyjnych". 
chowku własnym działaniem mogą wyłączyć zastosowanie ustawowego uprawnienia ograniczającego swobodę testowania, które uważają za zbędne w swoich stosunkach.

\subsection{Zachowek a sukcesja w przedsiębiorstwie}

W stanie faktycznym będącym podstawą rozstrzygnięcia SN uzasadnieniem zawarcia umowy zrzeczenia się zachowku był fakt, że spadkodawca prowadził przedsiębiorstwo i jego wolą było przekazanie tego przedsiębiorstwa wyłącznie jednemu z synów. Jest to przypadek, który dobrze obrazuje zasadność zawarcia omawianej umowy. Wolą spadkodawcy jest przekazanie spadku, w którego skład wchodzi przedsiębiorstwo, czy też analogicznie gospodarstwo rolne, jednemu synowi. Jeżeli poprzestałby wyłącznie na powołaniu jednego ze zstępnych na spadkobiercę, drugi nie zostałby powołany do spadku, ale za to byłby uprawniony do zachowku w wysokości 1/2 udziału spadkowego, który przypadałby mu, gdyby doszło do dziedziczenia ustawowego - czyli upraszczając wartość odpowiadającą 1/4 przedsiębiorstwa. Tak duże obciążenie finansowe może powodować, że znacząco zagrożony jest byt prowadzonej działalności gospodarczej. Wartość samych składników przedsiębiorstwa, czy gospodarstwa rolnego, nie przekłada się na jego dochody. Chcąc zaspokoić roszczenie zachowkowe bez sprzedaży aktywów, spadkobierca byłby zmuszony do przekazywania dużej części, albo nawet całości dochodów z działalności gospodarczej przez pewien czas na zaspokojenie roszczenia o zachowek. Często nie miałby nawet szansy, żeby dobrowolnie spłacić dług. W sytuacji, gdy uprawniony wszczyna przeciwko spadkobiercy egzekucję celem przymusowego wyegzekwowania wyroku zasądzającego roszczenie $z$ tytułu zachowku, a bieżące dochody wypracowane w toku prowadzonej działalności gospodarczej nie wystarczą na realizację wyroku, komornik zbędzie aktywa - przez co działalność przedsiębiorstwa jest zagrożona. Także umowa zrzeczenia się dziedziczenia nie rozwiązuje wszystkich problemów związanych z tą sytuacją, ponieważ powoduje zwiększenie wysokości zachowków innych uprawnionych, zatem również powoduje znaczne obciążenie przedsiębiorstwa ${ }^{29}$.

\section{Podsumowanie}

Należy zaaprobować dopuszczalność de lege lata zawarcia umowy zrzeczenia się zachowku. Wyrok SN z pewnością wpłynie na ujednolicenie praktyki o dopuszczalności tej czynności prawnej, jednak w dalszym ciągu zasadne jest wprowadzenie jej wyraźnej podstawy prawnej. Pomimo że w wielu przypadkach nie jest zasadne

29 Por. projekt ustawy o zarządzie sukcesyjnym przedsiębiorstwem osoby fizycznej, http://legislacja.rcl.gov.pl/projekt/12300657 (data dostępu: 30.07.2017 r.), aktualnie na etapie konsultacji publicznych i opiniowania. Proponowana ustawa jednak nie rozwiązuje problemów spadkobierców przedsiębiorców związanych z realizacją roszczeń zachowkowych. 
mnożenie regulacji prawnych, gdy istnienie danej instytucji można wywieść z innych przepisów czy zasad prawnych, jednak w odniesieniu do komentowanej instytucji zasadne jest przyjęcie wyraźnej regulacji, ze względu na pewność obrotu ${ }^{30}$. Potrzebne jest również jednoznaczne określenie wymogów związanych z tą czynnością prawną, w tym formy i jej skutków, np. w stosunku do obliczania zachowku innych uprawnionych osób.

Z zadowoleniem należy przyjąć kolejny judykat, który podkreśla istotność zasady swobody testowania we wszelkich instytucjach prawa spadkowego. Rzeczywistość społeczna i gospodarcza ulega ciągłym zmianom, modyfikacjom ulegają również funkcje prawa spadkowego. Aktualnie coraz ważniejsza staje się zasada jak największej autonomii spadkodawcy w decydowaniu o losach jego majątku po jego śmierci.

\section{BIBLIOGRAFIA}

Bieluk J., Rozliczenia związane ze spadkiem, Warszawa 2015.

Borysiak W., (w:) K. Osajda (red.), Kodeks cywilny. Komentarz, t. 3. Spadki, Warszawa 2013.

Doliwa A., Umowy dotyczące spadku, „Studia Prawa Prywatnego” 2008, nr 1.

Ganicz A., Uprawnieni i zobowiązani z tytułu zachowku w polskim prawie spadkowym, „Rejent” 2011, nr 2.

Hans W., Umowy dotyczące spadku, „Nowe Prawo” 1967, nr 2.

Katner W.J., (w:) W.J. Katner (red.), System prawa prywatnego. Prawo zobowiązań - umowy nienazwane. Tom 9, Warszawa 2015.

Knabe J., (w:) Ciszewski J. (red.), Kodeks cywilny. Komentarz, Lex 2014, komentarz do art. 1049.

Kosik J., (w:) System prawa cywilnego, t. 4, Wrocław 1976.

Księżak P., Zachowek w polskim prawie spadkowym, Warszawa 2012.

Niezbecka E., (w:) A. Kidyba (red.), Kodeks cywilny. Komentarz, t. 4: Spadki, Warszawa 2012.

Paliwoda R.M., Skutki prawne wydziedziczenia w polskim prawie spadkowym, „Przegląd Sądowy” 2013, nr 10.

Panek M., Dopuszczalność zrzeczenia się zachowku w prawie polskim, „Studia Iuridica Toruniensa” 2015, t. XVI.

Pazdan M., (w:) B. Kordasiewicz (red.), System prawa prywatnego. Prawo spadkowe, Tom 10, Warszawa 2015.

Pazdan M., (w:) K. Pietrzykowski (red.), Kodeks cywilny. Komentarz do artykułów 450-1088, t. II, Warszawa 2011.

Pazdan M., Umowa o zrzeczenie się dziedziczenia w polskim prawie spadkowym, „Rejent” 1997, nr 4. 
Dopuszczalność umowy zrzeczenia się zachowku. Glosa do uchwały Sądu Najwyższego...

Pietrzykowski J., (w:) J. Pietrzykowski (red.), Kodeks cywilny. Komentarz, t. 3, Warszawa 1972.

Pogonowski M., Wydziedziczenie. Zarys problematyki, „Rejent” 2005, nr 4.

Rott-Pietrzyk E., Umowa o zrzeczenie się dziedziczenia - uwagi „de lege lata” i „de lege ferenda”, „Rejent" 2006, nr 3 .

Skowrońska-Bocian E., Wierciński J., (w:) J. Gudowski (red.), Kodeks cywilny. Komentarz. T. VI. Spadki, Lex 2017, komentarz do art. 1049.

Smoter K., Zachowek jako ograniczenie testowania, „Państwo i Prawo” 2013, nr 9.

Stecki L., (w:) J. Winiarz (red.), Kodeks cywilny z komentarzem, t. 2, Warszawa 1989.

Szpunar A., Uwagi o prawie o zachowku, „Rejent” 2002, nr 6 (134).

Wolak G., Umowa zrzeczenia się dziedziczenia w polskim prawie cywilnym, Warszawa 2016.

Załucki M., Przyszłość zachowku w prawie polskim, „Kwartalnik Prawa Prywatnego” 2012, nr 2. 